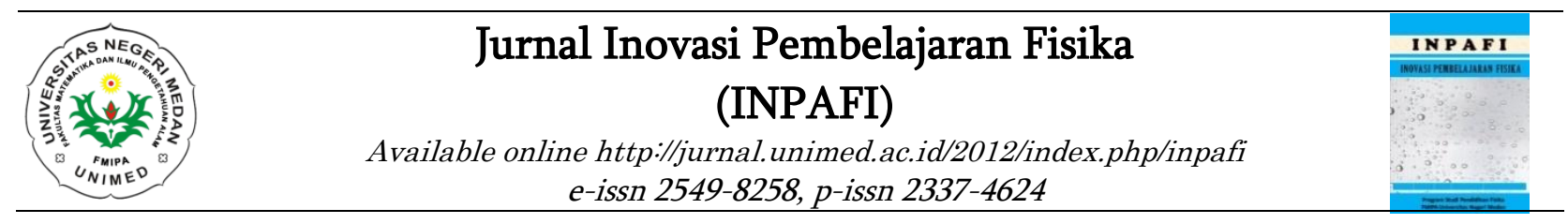

\title{
PENGARUH MODEL PEMBELAJARAN INKUIRI TERBIMBING TERHADAP KETERAMPILAN PROSES SAINS SISWA PADA PEMBELAJARAN FISIKA
}

\author{
Khairuna dan Jonny H. Panggabean \\ Jurusan Fisika FMIPA Universitas Negeri Medan \\ Khairuna411@gmail.com
}

Diterima: September 2018. Disetujui: Oktober 2018. Dipublikasikan: Februari 2019

\begin{abstract}
ABSTRAK
Penelitian ini bertujuan untuk mengetahui keterampilan proses sains siswa dalam proses pembelajaran menggunakan model pembelajaran inkuiri terbimbing dan menggunakan pembelajaran konvensional. Jenis penelitian ini adalah kuasi eksperimen dengan populasi seluruh siswa kelas XI IPA di MAN 2 Model Medan yang terdiri dari 9 kelas. Sampel penelitian diambil 2 kelas dengan random sampling yaitu kelas XI IPA 5 sebagai kelas eksperimen yang diberi perlakuan dengan menggunakan model pembelajaran inkuiri terbimbing dan kelas XI IPA 6 sebagai kelas kontrol yang menggunakan pembelajaran konvesional. Instrumen yang digunakan adalah essai tes sebanyak 8 soal. Hasil analisa data diperoleh nilai rata-rata pretes kelas ekperimen 31.36 dan kontrol 28.73. Pada uji normalitas dan homogenitas kedua kelas berdistribusi normal dan homogen, berarti kedua kelas memiliki kemampuan awal yang sama, kemudian dilakukan perlakuan yang berbeda dan diberikan postes. Hasil analisa data diperoleh nilai rata-rata postes kelas ekperimen 71.49 dan kelas kontrol 60.86. Hasil uji t postes diperoleh kesimpulan bahwa ada pengaruh dari penerapan model pembelajaran inkuiri terbimbing terhadap keterampilan proses sains siswa pada pembelajaran fisika
\end{abstract}

Kata kunci : model problem based learning, suhu dan kalor, kemampuan pemecahan masalah.

\begin{abstract}
This study aims to find out the science process skills of students in the learning process using a guided inquiry learning model and using conventional learning. This type of research is quasi-experimental with a population of all students of class XI IPA in Medan's MAN2 Model consisting of 9 classes. The study sample was taken 2 classes by random sampling, namely class XI IPA 5 as an experimental class treated by using guided inquiry learning model and class XI IPA 6 as a control class that uses conventional learning. The instruments used were 8 test essays. The results of data analysis obtained an average value of experimental class 31.36 pretest and control 28.73. In the normality and homogeneity tests both classes were normally distributed and homogeneous, meaning that both classes had the same initial ability, then different treatments were taken and given posttest. The results of data analysis obtained the posttest average value of experiment class 71.49 and control class 60.86. The results of the posttest $t$ test concluded that there was an influence from the application of a guided inquiry learning model to students' science process skills in physics learning.
\end{abstract}

Keywords: guided inquiry, conventional, science process skills 
Khairuna dan Jonny H. Panggabean ; Pengaruh Model Pembelajaran Inkuiri Terbimbing Terhadap Keterampilan Proses Sains Siswa Pada Pembelajaran Fisika

\section{PENDAHULUAN}

Pendidikan merupakan kebutuhan yang sangat penting bagi setiap manusia, sama halnya dengan kebutuhan sandang, pangan dan papan, sebab pendidikan merupakan suatu usaha secara sadar untuk mempersiapkan peserta didik lewat aktivitas pengajaran, tuntunan secara latihan untuk peranannya dimasa mendatang dalam menghadapi lingkungan secara selalu mengalami perkembangan. Pendidik dapat dijadikan sebagai tolak ukur untuk mengatahui tingkat keberhasilan dan perkembangan suatu negara. Guru sebagai garda terdepan dalam mencetak pribadi unggul, berprestasi dan berguna bagi kehidupan bangsa memiliki peranan yang sangat penting dalam hal ini, oleh karena itu muncul tantangan dalam dunia pendidikan untuk terus meningkat kualitasnya salah satunya melalui kegiatan proses pembelajaran disekolah.

Fisika sebagai salah satu bagian dari IPA merupakan ilmu pengetahuan yang mempelajari gejala-gejala alam melalui serangkaian proses ilmiah yang dibangun atas dasar sikap ilmiah dan hasilnya terwujud sebagai produk ilmiah yang tersusun atas tiga komponen terpenting berupa konsep, prinsip, dan teori yang berlaku secara universal (Trianto, 2015). Pembelajaran fisika akan lebih efektif jika melibatkan siswa secara aktif dalam kegiatan pembelajaran yaitu dengan memberikan kesempatan kepada siswa untuk mengkonstruk pengetahuannya sendiri melalui pengamatan dan eksperimen. Pengalaman mengkonstruk pengetahuannya sendiri akan membuat siswa merasakan makna pembelajaran yang dilakukannya serta juga melatih keterampilan yang ada pada diri siswa.

Rendahnya kemampuan sains siswa dipengaruhi oleh beberapa faktor, diantaranya kurikulum dan sitem pendidikan, pemilihan metode dan model pengajaran oleh guru, sarana dan fasilitas belajar, sumber belajar dan lain-lain (Ningsih dkk, 2015)

Masalah utama dalam pembelajaran pada pendidikan formal (sekolah) dewasa ini salah satunya adalah bahwa mata pelajaran fisika merupakan mata pelajaran yang sulit karena fisika memuat banyak rumus yang harus dihapal. Berdasarkan hasil observasi di MAN 2 Model
Medan. Beberapa tanggapan siswa dari 40 orang mengenai pelajaran fisika, antara lain $3 \%$ mengatakan sangat sulit, $46 \%$ mengatakan sulit, dan $5 \%$ mengatakan mudah, $46 \%$ mengatakan biasa saja.

Permasalahan yang terjadi pada proses pembelajaran lainnya adalah : 1) guru menjelaskan materi di depan kelas dengan ceramah sedangkan siswa mendegarkan dan menulis materi yang disampaikan guru atau dengan kata lain guru sebagai satu-satunya penyedia informasi, 2) guru kurang mengoptimalkan model-model pembelajaran, sehingga siswa jarang melakukan praktikum secara lansung, kondisi pembelajaran demikian membuat keterampilan poses sains siswa tidak berkembang.

Keterampilan proses sains (KPS) adalah pendekatan yang mengarahkan bahwa untuk menemukan pengetahuan memerlukan suatu keterampilan mengamati, melakukan eksperimen, menafsirkan data mengkomunikasikan gagasan dan sebagainya. Harlen dan Elsegeest (1992), membedakan KPS menjadi dua jenis, yang pertama KPS dasar, dan yang kedua adalah KPS terpadu. KPS dasar meliputi keterampilan mengamati, mengelompokkan, menyimpulkan mengukur/ menghitung, mengkomunikasikan, memprediksi, dan menemukan pola hubungan. Kemudian KPS terpadu meliputi merumuskan hipotesis, merumuskan penjelasan, mengumpulkan dan mengolah data, merancang percobaan, dan menerapkan konsep. Hasil penelitian sebelumnya menunjukkan bahwa keterampilan proses sains siswa yang dibelajarkan menggunakan inkuiri terbimbing memiliki pengaruh signifikan (Rizal, 2014)

Salah satu upaya yang dapat digunakan untuk mengembangkan keterampilan proses sains siswa adalah menggunakan model pembelajaran inkuiri terbimbing karena model pembelajaran inkuiri terbimbing merupakan model yang mempersiapkan peserta didik pada situasi untuk melakukan eksperimen sendiri secara luas agar melihat apa yang terjadi (Wulanningsih dkk, 2012).

Jauhari (2015) menyatakan inkuiri terbimbing biasanya digunakan terutama bagi 
siswa yang belum berpengalaman belajar dengan pendekatan inkuiri. Pada tahap-tahap awal pengajaran, diberikan bimbingan lebih banyak, kemudian pada tahap berikutnya, bimbingan tersebut dikurangi, sehingga siswa mampu melakukan proses inkuiri secara madiri.

Dampak pembelajaran dan dampak pengiring dari model pembelajaran inkuiri adalah: (1) dapat mengembangkan keterampilan proses sains, (2) model penyelidikan dapat dikembangkan secara kreatif, (3) menimbulkan semangat kreatif dan semangat belajar pada siswa, (4) memberikan kebebasan atau belajar secara otonomi pada siswa, (5) memungkinkan kerjasama dua arah (guru-siswa dan siswasiswa), (6) menekankan hakekat kesementaraan dari pengetahuan (Simbolon, 2015)

Berdasarkan latar belakang di atas, maka peneliti melakukan penelitian mengenai pengaruh model pembelajaran inkuiri terbimbing terhadap keterampilan proses sains siswa pada materi pokok elastisitas dan hukum hooke di MAN 2 Model Medan.

\section{METODE PENELITIAN}

Penelitian ini dilaksanakan di MAN 2 Model Medan, yang beralamat di jalan William Iskandar No 7A kota Medan, Medan Tembung.

Populasi dalam penelitian ini adalah semua siswa kelas XI. Sampel penelitian dipilih dengan menggunakan teknik penarikan sampel kelas acak (random sampling) sebanyak dua kelas. Satu kelas dijadikan sebagai kelas eksperimen yaitu kelas XI IPA 5 dengan jumlah siswa sebanyak 38 orang, dan satu kelas lagi dijadikan sebagai kelas kontrol yaitu kelas XI IPA 6 dengan jumlah siswa sebanyak 38 orang.

Variabel dalam penelitian ini ada dua jenis yaitu variabel bebas adalah model pembelajaran inkuiri terbimbing dan pembelajaran konvensional, dan variabel terikat adalah keterampilan proses sains siswa.

Jenis penelitian ini adalah kuasi eksperimen dengan desain control group pretest-posttest design (Sugiyono, 2011) yang ditunjukkan pada Tabel 1.
Tabel 1. Desain Penelitian Control Group Pretest-Posttest

Keterangan :

\begin{tabular}{|c|c|c|c|}
\hline Kelas & Pretes & Perlakuan & Postes \\
\hline Eksperimen & $\mathrm{T}$ & $\mathrm{X}_{1}$ & $\mathrm{~T}$ \\
& & & \\
Kontrol & $\mathrm{T}$ & $\mathrm{X}_{2}$ & $\mathrm{~T}$ \\
\hline
\end{tabular}

$\mathrm{T}=$ Pretes dan postes diberikan pada kelas eksperimen dan kelas kontrol sebelum dan setelah perlakuan

$\mathrm{X}_{1}=$ Pembelajaran dengan menggunakan model pemebelajaran inkuiri terbimbing

$\mathrm{X}_{2}=$ Pembelajaran dengan menggunakan konvensional

Instrumen penelitian berupa tes keterampilan proses sains siswa pada materi pokok elastisitas dan hukum hooke dalam bentuk essai yang terdiri dari 8 butir soal yang telah valid.

Sebagai uji prasyarat sebelum uji $t$, data dari kedua kelas sampel tersebut harus normal dan homogen. Uji normalitas dilakukan untuk mengetahui apakah sampel berasal dari populasi yang berdistribusi normal atau tidak. Uji normalitas data menggunakan uji Lilliefors. Uji homogenitas dilakukan untuk mengetahui apakah kedua kelompok kelas sampel penelitian memiliki varians yang sama dan dapat mewakili keseluruhan populasi atau tidak. Menurut (Sudjana, 2009) uji homogenitas data menggunakan uji $\mathrm{F}$ dengan kriteria pengujian: jika $F_{\text {hitung }}<F_{\text {tabel }}$ maka kedua sampel berasal dari populasi yang homogen pada taraf signifikan 0,05 dan sebaliknya. Uji hipotesis menggunakan uji t, jika analisis data menunjukkan bahwa, $t>t_{1-\alpha}$, atau nilai t hitung yang diperoleh lebih dari nilai $t_{1-\alpha}$, maka hipotesis $\mathrm{H}_{0}$ ditolak dan $\mathrm{H}_{a}$ diterima, dapat diambil kesimpulan bahwa model inkuri terbimbing berpengaruh terhadap keterampilan proses sains siswa. 
Khairuna dan Jonny H. Panggabean ; Pengaruh Model Pembelajaran Inkuiri Terbimbing Terhadap Keterampilan Proses Sains Siswa Pada Pembelajaran Fisika

\section{a. Hasil Penelitian}

Sebelum memulai pembelajaran, kedua kelas diberikan tes uji kemampuan awal (pretes) keterampilan proses sains (KPS) dengan hasil yang ditunjukkan pada Tabel 2.

Tabel 2. Data pretes pada kelas kontrol dan eksperimen

\begin{tabular}{|c|c|c|}
\hline Rentang Nilai & $\begin{array}{c}\text { Frekuensi } \\
\text { Kontrol }\end{array}$ & $\begin{array}{c}\text { Frekuensi } \\
\text { Eksperimen }\end{array}$ \\
\hline $4-13$ & 6 & 5 \\
\hline $14-23$ & 7 & 6 \\
\hline $24-33$ & 11 & 10 \\
\hline $34-43$ & 8 & 9 \\
\hline $44-53$ & 5 & 5 \\
\hline $54-63$ & 1 & 3 \\
\hline
\end{tabular}

Kelas eksperimen diberi perlakuan dengan model pembelajaran inkuiri terbimbing dan kelas kontrol diberi pembelajaran konvensional. Pembelajaran telah selesai dilaksanakan masing-masing pada materi elastisitas dan hukum hooke, kedua kelas diberi soal postes keterampilan proses sains yang identik dengan soal pretes yang bertujuan untuk melihat peningkatan pembelajaran setelah siswa diberi perlakuan. Hasil postes KPS dalam penelitian ini ditunjukkan pada Tabel 3.

Tabel 3. Data postes siswa pada kelas kontrol dan eksperimen

\begin{tabular}{|c|c|c|c|}
\hline \multicolumn{2}{|c|}{ Kelas Kontrol } & \multicolumn{2}{c|}{ Kelas Eksperimen } \\
\hline Nilai & Frekuensi & Nilai & Frekuensi \\
\hline $29-38$ & 3 & $37-46$ & 3 \\
\hline $39-48$ & 2 & $47-56$ & 3 \\
\hline $49-58$ & 7 & $57-66$ & 5 \\
\hline $59-68$ & 18 & $67-76$ & 13 \\
\hline $69-78$ & 5 & $77-86$ & 8 \\
\hline $79-88$ & 3 & $87-96$ & 6 \\
\hline
\end{tabular}

Uji normalitas data pretes dan postes kelas eksperimen dan kelas kontrol digunakan untuk mengetahui apakah data pretes dan postes berdistribusi normal. Uji normalitas dilakukan dengan menggunakan uji Lilliefors. Hasil uji normalitas data pretes dan postes kedua kelas dinyatakan dalam Tabel 4.

Tabel 4. Uji Homogenitas Data Pretes dan Postes

\begin{tabular}{|c|c|c|c|c|c|}
\hline & Lhitung & $\begin{array}{c}\text { Ltabel } \\
\alpha= \\
0,05\end{array}$ & Lhitung & $\begin{array}{c}\text { Ltabel } \\
\alpha= \\
0,05\end{array}$ & $\begin{array}{c}\text { Kesim- } \\
\text { pulan }\end{array}$ \\
\hline Eksperimen & 0.11 & \multirow{2}{*}{0.14} & 0.06 & \multirow{2}{*}{0.14} & \multirow{2}{*}{ Normal } \\
\hline Kontrol & 0.12 & & 0.11 & & \\
\hline
\end{tabular}

Tabel 4 menunjukkan bahwa Ltabel > Lhitung sehingga dapat disimpulkan bahwa data tersebut berasal dari populasi yang berdistribusi normal. Pengujian homogenitas data pretes kelas eksperimen dan kelas kontrol dilakukan dengan uji kesamaan dua varians, menunjukkan bahwa data dari kedua kelas tersebut adalah homogen yang berarti bahwa data yang diperoleh dapat mewakili seluruh populasi yang ada. Hasil uji homogenitas menggunakan uji F nilai pretes dan postes KPS ditunjukkan pada Tabel 5 .

Tabel 5. Uji Homogenitas Data Pretes dan

\begin{tabular}{|c|c|c|c|}
\multicolumn{4}{c}{ Postes } \\
\hline Data & Fhitung & Ftabel & Kesimpulan \\
\hline Pretes & 1,17 & \multirow{2}{*}{1,64} & Homogen \\
\hline Postes & 1,28 & & \\
\hline
\end{tabular}

Tabel 5 memperlihatkan bahwa keterampilan proses sains dengan $\mathrm{F}_{\text {tabel }}$ lebih besar dibandingkan Fhitung. Dapat disimpulkan bahwa data pretes dan postes KPS kelas eksperimen dan kontrol memiliki varians yang sama atau homogen dan dapat mewakili keseluruhan populasi.

Tabel 6. Perhitungan Uji t Data Pretes

\begin{tabular}{|c|c|c|c|c|}
\hline Data Pretes & $\begin{array}{c}\text { Nilai } \\
\text { rata- } \\
\text { rata }\end{array}$ & thitung & $\begin{array}{c}\alpha= \\
0,05\end{array}$ & Kesimpulan \\
\hline Eksperimen & 31.36 & \multirow{2}{*}{0,864} & 1,996 & $\begin{array}{c}\text { kemampuan } \\
\text { awal KPS } \\
\text { siswa sama }\end{array}$ \\
\hline Kontrol & 28.78 &
\end{tabular}

Tabel. 6 menunjukkan bahwa kemampuan awal KPS siswa pada kelas eksperimen sama dengan siswa kelas kontrol pada materi elastisitas dan hukum hooke. Setelah pemberian postes pada kedua kelas yang diberi perlakuan berbeda diperoleh kemampuan akhir yang berbeda seperti ditunjukkan pada Tabel 7 .

Tabel 7. Perhitungan Uji t Data Postes 


\begin{tabular}{|c|r|c|c|c|}
\hline Data Postes & $\begin{array}{c}\text { Nilai } \\
\text { rata-rata }\end{array}$ & thitung & $\begin{array}{c}\text { tabel } \\
\alpha= \\
0,05\end{array}$ & Kesimpulan \\
\cline { 1 - 2 } $\begin{array}{c}\text { Eksperime } \\
\mathrm{n}\end{array}$ & 71.49 & 3,56 & 1,66 & $\begin{array}{c}\text { Kemampuan } \\
\text { akhir KPS } \\
\text { siswa kedua } \\
\text { kelas berbeda }\end{array}$ \\
\hline Kontrol & 60.86 & &
\end{tabular}

Berdasarkan Tabel 7 diperoleh nilai rata-rata postes thitung $>$ tabel yaitu 3,56>1,6677 maka Ho ditolak dan Ha diterima, yang artinya bahwa ada pengaruh model pembelajaran inkuiri terbimbing terhadap keterampilan proses sains siswa pada materi pokok Elastisitas dan Hukum Hooke di kelas XI Semester I MAN 2 Model.

Keterampilan proses sains (KPS) siswa sesuai dengan hasil observasi aktivitas KPS pada kelas ekperimen yang diukur selama proses pembelajaran berlansung melalui praktikum yang dilaksanakan secara berkelompok Adapun hasil observasi KPS dapat dilihat pada Tabel 8.

Tabel 8. Hasil observasi KPS

\begin{tabular}{|c|c|c|c|}
\hline No & Aspek KPS & $\begin{array}{c}\text { Nilai } \\
\text { rata-rata } \\
(\%)\end{array}$ & Kriteria \\
\hline 1 & Mengamati & 58,55 & Kurang \\
\hline 2 & $\begin{array}{c}\text { Merumuskan } \\
\text { hipotesis }\end{array}$ & 52,63 & $\begin{array}{c}\text { Kurang } \\
\text { sekali }\end{array}$ \\
\hline 3 & $\begin{array}{c}\text { Merancang } \\
\text { percobaan }\end{array}$ & 80,26 & Baik \\
\hline 4 & $\begin{array}{c}\text { Mengumpulkan } \\
\text { dan mengolah data }\end{array}$ & 70,39 & Sedang \\
\hline 5 & $\begin{array}{c}\text { Merumuskan } \\
\text { penjelasan dan } \\
\text { mengidentifikasi } \\
\text { hubungan antar } \\
\text { variabel }\end{array}$ & 65,13 & Sedang \\
\hline 6 & Menyimpulkan & 75 & Sedang \\
\hline
\end{tabular}

Berdasarkan Tabel 8 menunjukkan skor rata-rata perindikator keterampilan proses sains siswa pada kelas eskperimen.

\section{b. Pembahasan}

Berdasarkan analisis data dengan menggunakan uji $\mathrm{t}$ menunjukkan bahwa ada pengaruh yang signifikan keterampilan proses sains siswa dengan model pembelajaran inkuiri terbimbing dengan pembelajaran konvensional.

Berdasarkan hasil observasi yang dilakukan dikelas eksperimen nilai rata-rata per indikator keterampilan proses sains siswa yakni, mengamati 58,55\% dengan kriteria kurang, hal ini terjadi karena siswa kurang dapat menggunakan panca indera dan alat praktikum dengan tepat dalam mengumpulkan informasi.

Merumuskan hipotesis 52,63\% dengan kriteria kurang sekali, pada aspek ke dua ini diharapkan siswa mampu merumuskan hipotesis yang sesuai dengan fenomena yang merupakan jawaban sementara dari permasalahan tentunya tepat sasaran, namun yang menjadi kendala masih banyak siswa yang belum bisa merumuskan hipotesis dengan benar dikarenakan mereka masih bingung dalam mengaitkan fenomena kedalam jawaban sementara atas permasalahan yang ada.

Merancang percobaan 80,26\% dan mengumpulkan serta mengolah data 70,39\%, dimana pada aspek KPS ini siswa sangat antusias dalam melakukan percobaan dan pada umumnya siswa sudah bisa merangkai kedalam bentuk kalimat dengan urutan yang tepat.

Merumuskan penjelasan dan mengidentifikasi hubungan antar variabel $65,13 \%$, pada aspek ke lima siswa mengalami kesulitan dalam meterjemahkan dari grafik yang telah dibuat kedalam kalimat.

Menyimpulkan 75\% dengan kriteria sedang dimana siswa dapat menyusun pikiran dalam bentuk kalimat yang menjelaskan bagaimana data yang mendukung atau tidak mendukung hipotesis. Hal ini membuktikan bahwa keterampilan proses sains dengan menggunakan model pembelajaran inkuiri terbimbing lebih baik dari pada pembelajaran konvensional, hasil penelitian ini, didukung penelitian yang dilakukan sebelumnya oleh Muliati dan Bukit, (2016) yang menjelaskan bahwa keterampilan proses sains siswa lebih meningkat dan lebih memahami indicator pada setiap komponen KPS.

Pembelajaran inkuiri menekankan kepada proses mencari dan menemukan. Joyce et all, (2009) menyatakan model pembelajaran 
inkuiri melibatkan siswa dalam masalah penelitian yang benar-benar orisinil dengan cara menghadapkan mereka pada bidang investigasi, membantu mereka mengidentifikasi masalah merancang cara-cara memecahkan masalah.

Proses inkuiri selama pembelajaran berdampak konstruktif yang memberi banyak peluang untuk meningkatkan keefektifan pembelajaran. Maka dari itu, siswa merasa senang dan tertarik untuk belajar karena siswa terlibat secara langsung dalam menemukan pengetahuan baru untuk di dirinya.

Pembelajaran yang disertai dengan kegiatan penyelidikan juga membuat siswa tertarik dan merasa senang dalam kegiatan pembelajaran. Selain itu, model pembelajaran ini menuntut siswa untuk aktif selama pembelajaran, melibatkan kemampuan berinteraksi, bekerja sama, dan berkolaborasi dalam kerja kelompok. Sehingga pembelajaran tidak hanya berdampak positif terhadap kemampuan pengetahuan dan keterampilan tetapi juga dalam hal kemampuan sosial.

Hasil penelitian ini sejalan dengan penelitian yang dilakukan oleh Nuraini dan Sahyar, (2014) bahwa ada interaksi antara kreativitas dengan model pembelajaran inkuiri terbimbing terhadap keterampilan proses sains siswa. Penelitian tersebut menunjukkan hasil yang sama mengenai keterampilan proses sains siswa menggunakan model pembelajaran inkuiri terbimbing. Rahmani, dkk (2016) juga menyatakan bahwa penerapan model pembelajaran inkuiri terbimbing dapat meningkatkan keterampilan proses sains siswa. Wahyudi dan Supardi, (2013) berdasarkan hasil penelitiannya menyatakan bahwa penerapan model pembelajaran inkuiri terbimbing dengan melatihkan keterampilan proses sains dapat meningkatkan hasil belajar di kelas X-6 SMAN 1 Sumenep.

Berdasarkan hasil penelitian sebelumnya dan dari hasil penelitian yang dilakukan di MAN 2 Model Medan pada siswa kelas XI pada materi pokok elastisitas dan hukum hooke terbukti bahwa dengan model pembelajaran inkuiri terbimbing memberikan pengraruh terhadap keterampilan proses sains siswa.

Adapun kendala yang dihadapi dalam penelitian ini yaitu kondisi kelas yang sulit dikontrol karena kesempatan diskusi selama proses pembelajaran memberi peluang pada siswa untuk ribut sehingga mengganggu kelompok lain, lembar kerja tidak terisi penuh, alokasi waktu yang terbatas, sehingga hasil diskusi kelompok tidak dapat disampaikan seluruhnya ke depan kelas.

\section{KESIMPULAN DAN SARAN}

\section{a. Kesimpulan}

Keterampilan proses sains siswa pada kelas eksperimen lebih besar dari kelas kontrol, hal ini menunjukkan adanya pengaruh model pembelajaran inkuiri terbimbing terhadap keterampilan proses sains peserta didik pada materi Elastisitas dan hukum Hooke dengan diperoleh thitung $>$ tabel $=3,56>1,6694$

\section{b. Saran}

Berdasarkan kesimpulan yang telah dikemukakan, sesuai dengan hasil penelitian yang diperoleh di MAN 2 Model Medan, maka peneliti memberikan saran

1. Banyak siswa pada saat proses pembelajaran masih mengalami kesulitan mengisi LKPD, sehingga siswa cenderung lebih suka pada saat melakukan percobaan saja, untuk mengatasi keadaan yang harus diantisipasi dan dilakukan antara lain adalah penyusunan dan pembuatan lembar kerja peserta didik yang komunikatif, terarah dan terbimbing sehingga mudah dimengerti dan dipahami siswa.

2. Dilihat dengan karakter siswa, siswa belum terbiasa dengan menggunakan model pembelajaran inkuiri terbimbing maka sebaiknya siswa mulai dilatih untuk melakukan percobaan-percobaan sederhana ketika pembelajaran fisika agar memiliki respon yang cepat 
3. Siswa harus dibimbing dengan memberikan latihan yang cukup untuk meningkatkan keterampilan proses sains fisika siswa

\section{DAFTAR PUSTAKA}

Fatmi, N dan Sahyar., (2014), Pengruh model Pembelajaran Inkuiri Terbimbing dan Kreativitas terhadap Keterampilan Proses Sains pada Siswa SMA, Jurnal Pendidikan Fisika, 3(1), 47-52

Harlen, W and Elstgeest, J., (1992), UNESCO Sourcebook for Science in the Primary School, Imprimerie de Is Manutention, France

Jauhar, M., (2015), Implementasi Paikem dari Behavioristik sampai Kontruktivistik, Jakarta : Prestasi Pustakakarya

Joyce, B., Weil, M, and Calhoun, E., (2009), Model of Teaching Edisi Delapan. Yogyakarta: Pustaka Belajar

Muliati, S dan Nurdin B., (2016), Pengaruh Model Pembelajaran inquiry Training terhadap Keterampilan Proses Sains Pada Pembelajaran Fisika, Jurnal Ikatan Alumni Fisika Universitas Negeri Medan, 2 (2): 2461-1247

Ningsih, E, N, Siswoyo, dan Astra, M, I., (2015). Pengaruh Metode Pogil (Process Oriented Guided Inquiry Learning) terhadap Keterampilan Proses Sains Siswa pada Materi Suhu dan Kalor Kelas X SMA, Jakarta: Jurnal Nasional Fisika, 4: 2476-9398

Rahmani, Halim, A., dan Jalil Z., (2016), Pengaruh Model Pemebalajaran Inkuiri Terbimbing untuk Meningkatkan Keterampilan Poses Sains Siswa Sekolah Dasar, Jurnal Pencerahan, 10(2): 74-80

Rizal, M., (2014), Pengaruh Pembelajaran Inkuri Terbimbing dengan Multi Representatif terhadap Keterampilan
Proses Sains dan Penguasaan Konsep IPA Siswa SMP, Jurnal Pendidikan Sains, 2(3): 159-165

Simbolon, H,D., dan Sahyar., (2015), Pengaruh Model Pembelajaran Inkuiri Terbimbing Berbasis Eksperimen Riil dan Laboratorium Virtual terhadap Hasil Belajar Fisika Siswa, Jurnal Pendidikan dan Kebudayaan, 21(3) : 229-315

Sudjana, (2009), Metoda Statistika, Tarsito, Bandung

Sugiyono, (2011), Metoda Penelitian kuantitatif dan $R \& D$, Alfabeta, Bandung

Trianto, (2015), Model Pembelajaran Terpadu: Konsep, Strategi, dan Implementasinya Dalam KTSP, Bumi Aksara, Jakarta

Wahyudi, L.E dan Supardi, I., (2013), Penerapan Model Pembelajaran Inkuiri Terbimbing Pokok Bahasan Suhu Kalor untuk Melatihkan Keterampilan Proses Sains terhadap Hasil Belajar Di SMAN1 Sumenep, Jurnal Inovasi Pendidikan Fisika, 2(2): 62-65

Wulanningsih, S., Prayitno, A. B., dan Probosar, M, R., (2012), Pengaruh Model Pembelajaran Inkuiri Terbimbing terhadap Keterampilan Proses Sains ditinjau dari Kemampuan Akademik Siswa SMA Negeri 5 Surakarta, Jurnal Pendidikan Biologi, 4(2), 33-43 